\title{
POPULISME ISLAM DALAM GERAKAN 212
}

\section{(Studi Kasus: Lima Organisasi Keagamaan)}

\section{Dea Bhakti Pratama}

Prodi Sosiologi, Fakultas Ilmu Sosial, Universitas Negeri Jakarta

deabhakti16@gmail.com

Diterima Redaksi: 24-03-2021 | Selesai Direvisi: 09-05-2021 | Diterbitkan Online 04-06-2021

\begin{abstract}
This paper aims to describe the 212 movement as a phenomenon of Islamic populism based on socio-religious movements followed by various Islamic organizations and their contradictions with other Islamic organizations. The results showed that the 212 movement phenomenon was followed by various religious groups, especially Islam, participation was based on various forms of motivation, demands, principles and organizational ideology. Pros and cons tend to be based on interpretations of religious teachings as well as ideology and organizational principles. This paper uses a qualitative research method by paying attention to the depth of information and exploring the meaning behind a symptom. The results of the research are then analyzed using the concept of mass mobilization and Islamic populism in the study of social movements that lead to the populist movement. The research findings also show that there is a relationship between social movements and Islamic populism as evidenced by the finding of chains of equivalens and empty signifiers which have implications for the formation of political frontier in the Islamic populism movement 212.
\end{abstract}

Keywords: Movement, Populism, Islam, Mobilization, Chains of Equivalens.

\begin{abstract}
Abstrak
Paper ini bertujuan untuk mendeskripsikan gerakan 212 sebagai suatu fenomena populisme Islam berbasis gerakan sosial keagamaan yang diikuti oleh berbagai organisasi Islam serta kontradiksinya dengan organisasi Islam lain. Hasil penelitian menunjukkan fenomena gerakan 212 diikuti oleh berbagai kelompok keagamaan khususnya Islam, keiikutsertaan didasari oleh berbagai bentuk motivasi, tuntutan, prinsip dan ideologi organisasi. Pro dan kontra cenderung didasari oleh pemaknaan mengenai ajaran agama dan juga ideologi serta prinsip organisasi. Paper ini menggunakan metode penelitian kualitatif dengan memberikan perhatian pada kedalaman informasi serta menggali makna dibalik suatu gejala. Hasil penelitian tersebut kemudian dianalisa menggunakan konsep mobilisasi massa dan populisme Islam dalam kajian gerakan sosial yang mengarah kepada gerakan populisme. Temuan penelitian juga menunjukkan terdapat keterkaitan antara gerakan sosial dengan populisme Islam dibuktikan dengan ditemukannya chains of equivalens dan empty signifier yang berimplikasi pada pembentukan political frontier dalam gerakan populisme Islam 212.
\end{abstract}


Kata Kunci: Gerakan, Populisme, Islam, Mobilisasi, Chains of Equivalens.

\section{Pendahuluan}

Terbukanya ruang-ruang sekaligus kran-kran dalam demokrasi berimplikasi pada berkembangnya pemikiran dan tindakan dari individu maupun kelompok. Berkembangnya pemikiran dan tindakan dapat berupa munculnya organisasi dan komunitas yang dilandasi oleh konstruksi makna kolektif. Pelebaran dan perkembangan dalam konstruksi makna sebagai elemen ideologi berlandaskan ide membuat ruang-ruang baru berbasis identitas untuk dijadikan ideologi muncul ke permukaan fenomena sosial. Identitas agama menjadi salah satu ideologi yang bersumber dari terbukanya ruang-ruang baru dalam pluralisme ide dalam perkembangan modernisme. Hal tersebut juga berimplikasi pada munculnya beberapa gerakan sosial baru berbasis ide dan konstruksi makna atas dasar agama. Munculnya beragam gerakan sosial keagamaan juga merupakan bagian dari perbedaan pemahaman dan aktualisasi atas tafsir teks-teks ajaran agama yang ada (Kusmanto, 2017:86). Kondisi dan situasi tersebut dapat dijadikan peluang oleh individu maupun kelompok tertentu untuk membentuk sistem komunikasi, koneksi serta relasi.

Beberapa terminologi dalam gerakan sosial cenderung dapat dikatakan serupa dengan populisme, hal ini didasarkan pada pengertian yang lebih politis. Menurut Laclau praktik populisme terletak pada konstruksi politik akan penyatuan tuntutan atau aspirasi yang homogen dari masyarakat yang heterogen dalam dikotomi antara tuntutan rakyat yang tidak terpenuhi dan kekuasaan yang tidak responsif (Margiansyah, 2019:50). Suatu hal yang perlu diketahui bahwa, dalam kasus ontologi politik Ernesto Laclau, pengalaman Peronisme Argentina yang menjadi latar belakang pemikiran Laclau tentang politik, termasuk teorinya tentang antagonisme dan populisme muncul (Marchart, 2018:109). Populisme berangkat dari adanya sebuah momentum yang didasari oleh demands dan interest berupa tuntutan sosial. Walaupun menggunakan simbol-simbol identitas, namun yang ditampilkan adalah agenda dan tuntutan. Kategori tuntutan tersebut dapat berubah melalui beberapa sebuah klaim melalui beberapa transisi. Transisi disini dimaksudkan pada adanya relasi yang mengartikulasikan beberapa tuntutan dan permintaan yang tidak terpenuhi (Laclau, 2005:72). Tuntutan tersebut kemudian terakumulasi dengan tuntutan-tuntutan lainnya yang sebenarnya di dalam tuntutan tersebut terdapat sebuah chain of equivalence yakni situasi yang setara dalam kadar pemaknaan tuntutan. Jadi, adanya hal tersebut maka lahir sebuah formasi perbatasan internal, dikotomisasi spektrum politik lokal melalui munculnya rantai ekuivalen dari tuntutan yang tidak terpenuhi. 
Tepat pada titik ini tuntutan berubah menjadi klaim tertentu yang didasarkan oleh penggabungan tuntutan menjadi singularitas dan tuntutan populer (Laclau, 2005:73).

Politik Islam maupun gerakan sosial Islam juga dapat dipahami sebagai respon populis terhadap kontradiksi sosial (Hadiz, 2016:33). Hal ini dapat dikatakan karena terdapat korelasi antara organisasi Islam dan konstruksi makna atas ajaran agama yang dapat mendorong munculnya gerakan sosial populisme dengan beragam organisasi keagamaan sebagai basis sosialnya. Lebih dari itu, populisme membutuhkan pembagian dikotomis masyarakat menjadi dua kubu, yang satu menampilkan dirinya sebagai bagian yang mengklaim sebagai keseluruhan dalam subjek kolektif, yang diketahui bahwa dikotomi ini melibatkan pembagian antagonis dari bidang sosial, sebagai sebuah syarat dari konstitusinya. Maka, konstruksi identitas global yang bersumber dari ikatan ekuivalen sejumlah tuntutan sosial yang mengkristal menjadi subjek kolektif merupakan sebuah wacana proyek emansipasi (Laclau, 2005:93). Salah satu fenomena populisme yang didasarkan pada konstruksi agama adalah gerakan 212. Hal ini terlihat dari partisipan dari berbagai organisasi Islam dalam yang memiliki beberapa elemen populisme dan dengannya sekaligus menjadi embrio bagi populisme Islam . Keikutsertaannya juga telah melampaui segi- segi kelas sosial dan cenderung mempermasalahkan suatu keprihatinan golongan agama tertentu yakni isu penistaan agama Islam. Isu penistaan agama dalam hal ini menemukan momentumnya ketika gubernur DKI Jakarta pada saat itu yakni Basuki Tjahja Purnama atau Ahok mengkampanyekan diri ditengah situasi Pilgub DKI Jakarta mengenai tafsir Surat Al-Maidah ayat 51.

Merujuk pada beberapa penelitian sejenis mengenai populisme Islam, menunjukkan bahwa fenomena populisme Islam di Indonesia didasarkan atas adanya krisis representasi dalam konteks absennya gerakan politik yang progresif yang wadah bagi kelas yang terpinggirkan. Lebih dari itu, tidak terbangunnya basis sosial multi kelas serta borjuasi Muslim yang kuat dan munculnya produk depolitisasi yang panjang serta dominasi ekonomi oleh borjuasi domestik Cina, menghasilkan aliansi populisme Islam di Indonesia yang terfragmentasi (Mudhoffir dkk, 2017:55). Hal tersebut berimplikasi pada bentuk populisme di Indonesia yang cenderung bertujuan sebagai mobilisasi elektoral semata. Melihat fenomena populisme di Belgia, perubahan sosial menjadi akibat dari munculnya populisme yang terjadi di Belgia. Permasalahan mengenai imigrasi menjadi pemicu langsung atas munculnya populisme sayap kanan. Para pendatang dipandang mengganggu tatanan sosial serta mengancam perimbangan kekuasaan karenanya merugikan penduduk asli Belgia (Abts dkk, 2019:332). Hal tersebut menjadikan munculnya peluang populisme di Belgia yang beraliansi secara vertikal dan berlanjut pada kontestasi elektoral pada pemilu Belgia. 
Ketertarikan penulis untuk meneliti tentang populisme Islam dalam gerakan 212 didasari atas adanya strategi dan basis-basis sosial dari organisasi keagamaan yang turut serta dalam gerakan 212. Diketahui bahwa populisme Islam dan gerakan 212 didasarkan atas munculnya aliansi universal diantara berbagai organisasi Islam. Hal tersebut tentu saja dapat memperkaya dinamika terkait gerakan sosial keagamaan dan populisme Islam khususnya dalam gerakan 212. Maka dari itu perlunya kajian lebih lanjut serta mendalam mengenai gerakan 212 dan populisme Islam. Kajian mendalam meliputi pencarian aktor dan elit populis dalam relasi antar organisasi keagamaan dalam konteks gerakan 212. Dari adanya latar belakang diatas, maka permasalahan penelitian yang peneliti angkat adalah tentang bagaimana bentuk relasi dan basis sosial organisasi Islam dalam fenomena gerakan 212 serta bagaimana bentuk populisme Islam dalam fenomena gerakan 212.

Tujuan penelitian ini adalah untuk mendeskripsikan gerakan 212 sebagai suatu fenomena populisme Islam berbasis gerakan sosial keagamaan yang diikuti oleh berbagai organisasi Islam serta kontradiksinya dengan organisasi Islam lain. Lebih lanjut untuk mendeskripsikan gerakan sosial 212 sebagai gerakan populisme dengan menggunakan analisis Ernesto Laclau yang berimplikasi pada polarisasi dalam tubuh sosial masyarakat. Hasil penelitian ini dapat dijadikan sebagai bahan pustaka untuk pengembangan kajian di bidang Sosiologi, khususnya dalam permasalahan mengenai gerakan sosial berbasis keagamaan dan populisme Islam. Hasil penelitian juga diharapkan dapat menjadi referensi bagi peneliti selanjutnya yang memiliki topik penelitian yang serupa yakni gerakan sosial dan populisme Islam serta diharapkan mampu menjadi sumber informasi mengenai gerakan sosial keagamaan dan populisme Islam dalam kajian sosiologi.

\section{Metode Penelitian}

Penelitian ini menggunakan metode kualitatif yakni metode penelitian natural atau alamiah dengan pertimbangan melakukan penelitian dalam latar yang sesungguhnya sehingga objek tidak berubah, baik sebelum maupun sesudah melakukan penelitian. Metode kualitatif memberikan perhatian pada kedalaman informasi, menggali makna dibalik gejala dan oleh karena itu penelitian ini bersifat studi kasus (Kutha, 2016:97). Pada konteks penelitian ini, peneliti menangkap suatu fenomena dari adanya gerakan 212 yang melibatkan berbagai organisasi keagamaan seperti FPI, Persis dan Al-Irsyad Al-Islamiyah. Ketiga organisasi tersebut penulis pilih karena memiliki peranan yang sangat besar dalam munculnya gerakan 212. Beberapa elit organisasi juga terlibat langsung menjadi aktor populis yang tergabung dalam aliansi GNPF MUI yang merupakan organisasi populis dalam gerakan 212. Lebih dari itu, peneliti juga mengklasifikasikannya dengan yang tidak sepaham terhadap gerakan 212 
yakni Jamaah Tabligh dan Salafi. Kedua organisasi tersebut penulis pilih didasarkan atas kontradiksinya dengan gerakan 212, terlebih organisasi tersebut merupakan organisasi Islam yang tidak sepaham dengan gerakan 212. Metode pencarian data menggunakan model teknik snow ball atau dari orang pertama yang ditemui akan menunjukkan relasi dan keterhubungannya dengan informan lain.

Peneliti membagi dua klasifikasi informan yakni informan dengan latar belakang organisasi yang pro dan ikut serta secara langsung dalam gerakan 212 dan informan yang kontra dengan gerakan 212. Untuk yang pro, peneliti mengawalinya dengan melakukan wawancara dengan informan yang pernah ikut langsung dalam gerakan 212. Level informan dalam gerakan 212 sendiri meliputi Ketua Departemen Dakwah Al-Irsyad Al-Islamiyah, Ketua Departemen Sosial Al-Irsyad Al-Islamiyah, Ketua Departemen Olahraga dan Kesenian AlIrsyad Al-Islamiyah, Ketua Tim Advokasi FPI, Ketua Hilal Merah FPI, Wakil Ketua Pimpinan Wilayah Persis Jakarta, Ketua HIMA Persis Jakarta, Anggota Jamaah Tabligh, Pengikut Salafi, Ketua Departemen Lembaga Dakwah Kampus dan Anggota Islamic News Agency. Kemudian setelah itu, peneliti meminta untuk dipertemukan kepada pemimpin dan anggota organisasi Islam yang turut hadir dan menjadi aktor penggerak gerakan 212. Diketahui GNPF merupakan organisasi lintas ormas yang menjadi penggerak gerakan 212. Untuk data mengenai kontradiksi cenderung sulit, tetapi peneliti berhasil mendapatkan data informan dengan meminta rujukan mengenai organisasi atau pemahaman tentang Islam yang kurang begitu populer dari salah satu informan yang pro terhadap gerakan 212. Dengan cara tersebut peneliti menemukan data dan informasi dari organisasi Islam yang kontradiksi dan tidak sepaham terhadap gerakan 212 .

\section{Hasil dan Pembahasan}

\section{Gerakan 212, Embrio Populisme Islam dan Chains of Equivalens}

Populisme didasari oleh sebuah hegemoni dan relasi diskursif antar aktor. Hegemoni didasarkan oleh adanya kekuatan antagonis dan juga ketidakstabilan batas yang memisahkan mereka (Laclau and Mouffe, 2001:135). Batas disini dimengerti melalui beragamnya identifikasi serta terdiferensiasi relasi-relasi diantara tubuh sosial. Kemudian, terdiferensiasinya bentuk-bentuk relasi diantara tubuh sosial tersebut ditransformasi melalui proses kondensasi yang akan dijelaskan pada bagian ini. Hal ini berimplikasi pada munculnya empty signifier, yakni sebuah penanda kosong, yang mengandung ketidakstabilan diantara beragamnya identifikasi partikular. Lahirnya penanda kosong mengandung konsekuensi munculnya nodal point yakni singularitas yang membuatnya rapat dan menyatu yang terbentuk diantara berbagai partikularitas atas beragam bentuk tuntutan yang bertransformasi menjadi nodal point, termanifestasi dalam transisinya menjadi klaim. Maka dalam hegemoni harus 
terdapat seorang subjek yang merupakan aktor yang mampu mengartikulasikan nodal point dalam situasi dan keadaan terbentuknya empty signifier (Laclau and Mouffe, 2001:134). Hanya situasi dan keberadaan itulah yang membuka kemungkinan terbentuknya nodal point ke kubu yang berlawanan. Dalam mewujudkan nodal point maka beberapa strategi harus dilakukan terlebih dahulu, yakni partikularitas harus segera dilampaui dan perjuangan hegemoni merupakan salah satu strategi dalam mewujudkan hal tersebut. Maka, dalam konteks populisme yang telah diradikalisasi oleh Laclau, hegemoni dapat diartikan sebagai sebuah upaya dan kontingensi yang memungkinkan bagi terbentuknya solidaritas diantara berbagai kelompok.

Dalam konteks gerakan 212 maka sumbangsih pemikiran Laclau untuk menjelaskan fenomena tersebut menjadi lebih komprehensif, detail dan mendalam. Munculnya hysteria massa dalam medium gerakan sosial yang termanifestasi dalam gerakan 212 berasal dari munculnya chains of equivalens yakni, munculnya rantai kesetaraan diantara organisasi Islam. Kesetaraan dalam hal ini adalah bentuk universalitas atas adanya suatu perbedaan, maka merunut dari pemikiran dan konsepsi Laclau, universalitas adalah bagian yang secara integral dengan partikularitas. Keduanya saling berhubungan dan ketergantungan melalui adanya relasi-relasi yang terhubung satu sama lain, tidak akan ada universalitas jika tidak ada partikularitas, tidak ada kesetaraan jika tidak ada perbedaan. Munculnya rantai kesetaraan tidak lepas dari adanya subjek dan aktor politik yang menghegemoni berbagai rantai partikularitas dan perbedaan menjadi chains of equivalens yakni, rantai kesetaraan.

Diketahui inti terdalam dari struktur chains of equivalens adalah diferensiasi dalam partikularistik. Elemen partikularistik ditemukan melalui munculnya chains of equivalens dalam GNPF MUI yang beranggotakan lintas organisasi Islam. Seperti yang menjadi eviden dalam analisis ini adalah tiga organisasi yang secara serentak membangun struktur internal populisme melalui relasi rantai kesetaraan. Ketiga organisasi Islam yang berelasi secara ekuivalen dalam konteks penelitian ini diantaranya FPI, Persis dan Al-Irsyad Al-Islamiyah. Dari adanya hal tersebut, maka terdapat heterogenitas dan segmentasi prinsip, ideologi dan kegiatan dalam hal keikutsertaan organisasi Islam dalam gerakan 212 yang tergabung dalam GNPF MUI. Diketahui partikularitas FPI terkandung didalam ideologi, prinsip dan kegiatan, prinsip dan ideologi yang dianut oleh FPI sendiri adalah NKRI bersyariah yang diwujudkan dalam konsep "Rumah Bersih Aswaja". NKRI bersyariah sendiri memiliki pengertian yakni, membersihkan NKRI dari sesuatu yang menyimpang sesuai ajaran Ahlus Sunnah Wal Jama'ah. Untuk mewujudkan "Rumah Bersih Aswaja" FPI menggunakan tiga medan juang, diantaranya medan juang dakwah, hisbah konstitusional dan jihad yang ketiganya memiliki mekanismenya 
masing-masing. Bentuk kegiatan dari organisasi FPI diantaranya menghancurkan dan menyegel tempat prostitusi, tempat perjudian dan pabrik miras yang masuk dalam medan juang hisbah konstitusional, Majlis Ta'lim yang membahas isu-isu modern seperti LGBT dan isu liberalisme. Medan juang hisbah konstitusional sendiri berarti dilakukan secara tegas kepada masyarakat untuk kembali ke jalan kebaikan melalui cara-cara konstitusional. Hal ini melibatkan aparatur negara seperti kepolisian dan juga telah mendapatkan izin dari kepolisian untuk menghancurkan dan menyegel tempat prostitusi, tempat perjudian dan pabrik miras. Hal ini dilakukan guna mewujudkan "Rumah Bersih Aswaja” dan NKRI bersyariah.

Sedangkan partikularitas Persis dibuktikan dalam ideologi dan prinsip yang didasarkan pada suatu aqidah dalam Al-Qur'an dan Sunnah. Persis memiliki prinsip yakni harus diimplementasikannya Al-Qur'an dan Sunnah di dalam kehidupan sehari- hari sebagai wujud miniatur Islam. Keharusan dalam menjaga izzah dan marwah merupakan hal yang utama yang harus dipegang oleh para anggota Persis. ${ }^{1}$ Hal tersebut memiliki pengertian menjaga kehormatan Islam dan menjaga serta membela panduan umat Islam yakni Al-Qur'an dan Sunnah. Persis juga bergerak dalam bidang pendidikan, dakwah dan politik. Dalam bidang pendidikan, Persis telah mendirikan pesantren dan dalam bidang dakwah Persis memiliki tujuan untuk menghapuskan dan meluruskan segala bentuk takhayul, bid'ah dan kurofa. Terdapat juga kegiatan lain di luar pendidikan dan dakwah, yakni kegiatan yang memiliki disposisi politis seperti pengkaderan yang dilakukan melalui bidgar siasah. ${ }^{2}$

Partikularitas ketiga terletak pada organisasi Al-Irsyad Al-Islamiyah, partikularitas AlIrsyad Al-Islamiyah terletak pada prinsip dasarnya, yakni wasaton. ${ }^{3}$ Pengertian dari prinsip tersebut membahas mengenai posisi dan letak ideologi Al-Irsyad Al-Islamiyah. Secara praktis memiliki pengertian moderat, tidak kiri dan juga tidak kanan, maka berada ditengah-tengah. Prinsip selanjutnya berbicara mengenai larangan, terdapat tiga larangan yang diharuskan oleh Al-Irsyad Al-Islamiyah yakni takhayul, bid'ah dan kurofa. Al-Irsyad Al-Islamiyah sendiri bergerak dibidang pendidikan, dakwah dan sosial. Misi ini awalnya bertujuan untuk menyamaratakan pendidikan diantara kalangan keturunan arab dan pribumi. Al-Irsyad AlIslamiyah dalam melakukan kegiatan rutinnya dengan mengelaborasi misi mengenai pendidikan, dakwah dan juga misi sosial.

\footnotetext{
${ }^{1}$ Izzah dan marwah memiliki pengertian sebagai usaha untuk menjaga kehormatan Islam serta membela panduan Al-Qur'an dan Sunnah.

${ }^{2}$ Bidgar Siasah berarti proyeksi para kader organisasi untuk tampil sebagai penggerak roda organisasi Persis, baik sebagai pengelola atau pemimpin (tasykil) organisasi, maupun untuk menjadi pejabat-pejabat publik yang direkomendasikan oleh organisasi.

${ }^{3}$ Wasaton berarti moderat, tidak kiri dan juga tidak kanan, maka disposisinya berada ditengah-tengah.
} 


\section{Skema No. 1}

\section{Partikularitas Organisasi Dalam Gerakan 212}

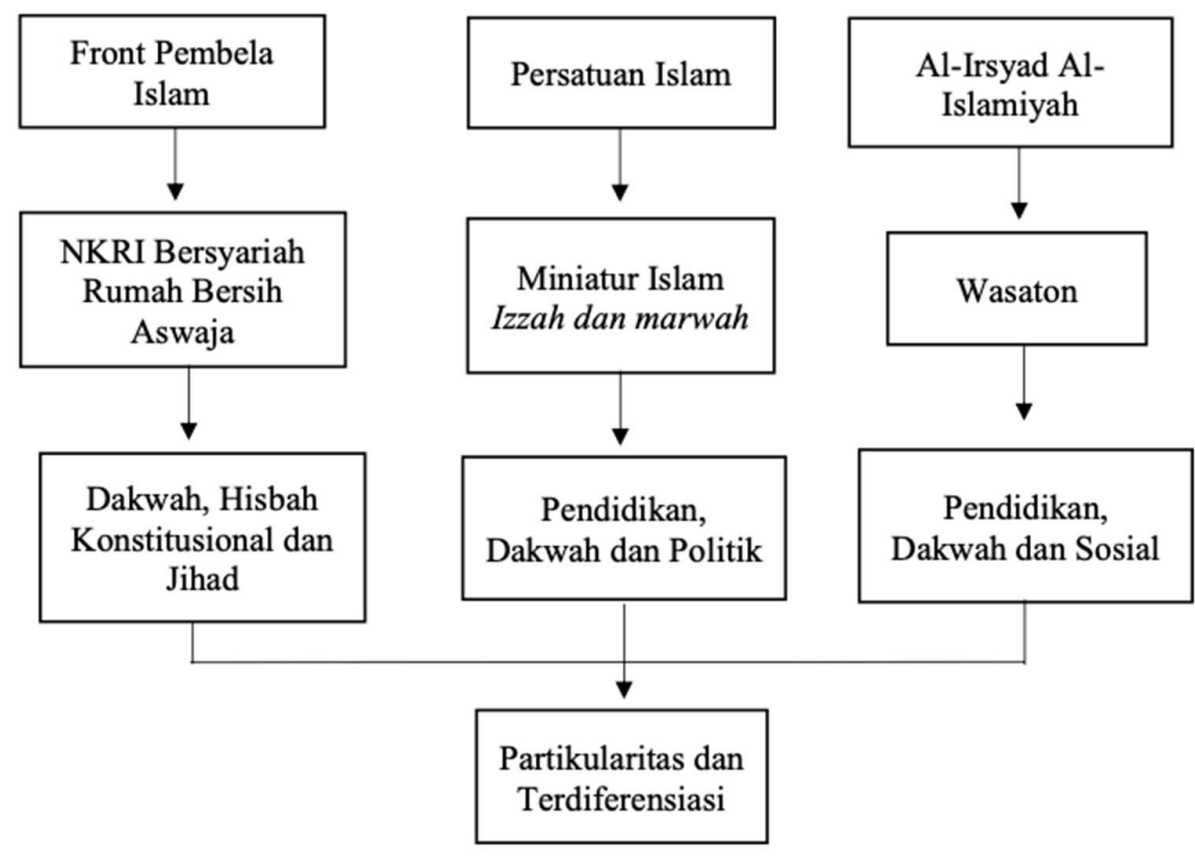

(Hasil Analisa Peneliti, 2021)

Berdasarkan skema diatas diketahui bahwa ketiga organisasi memiliki partikularitas yang terdiferensiasi di ranah ideologi, prinsip serta misi organisasi. Konteks dalam skema tersebut memberikan sebuah eviden atas fondasi struktur internal dalam populisme. Heterogenitas dan segmentasi prinsip, ideologi dan kegiatan dalam hal keikutsertaan organisasi Islam dalam gerakan 212 tersebut yang akan menentukan terbentuknya relasi kesetaraan dan menciptakan empty signifier dalam gerakan 212. Bagaimana sebuah populisme dibangun atas dasar diferensiasi perbedaan yang besar. Namun, dari adanya diferensiasi tersebut terdapat persamaan universalistik yang diperjuangkan oleh subjek dan elit antagonisme. Hal tersebut akan dibahas pada analisis selanjutnya.

Relasi kesetaraan atau chains of equivalens yang muncul dalam gerakan 212 merupakan rangkaian artikulasi perjuangan hegemonik yang dilakukan oleh berbagai aktor antagonis demi terwujudnya suatu polarisasi dalam tubuh masyarakat. Peranan aktor antagonis dalam membentuk relasi tersebut merupakan bagian penting dalam menjelaskan fenomena struktur internal dalam populisme. Dalam artikulasi hegemonik haruslah terdapat seorang subjek yang merupakan aktor yang mampu mengartikulasikan tuntutan. Struktur internal dalam 
populisme berangkat dari adanya sebuah momentum yang didasari oleh demands dan interest berupa tuntutan sosial. Walaupun menggunakan simbol-simbol identitas, namun yang ditampilkan adalah agenda dan tuntutan. Kategori tuntutan tersebut kemudian bertransformasi dengan didorong adanya elit hegemonik. Elit hegemonik didasarkan dalam gerakan populisme 212 didasarkan adanya elit dalam organisasi keagamaan yang mampu mengartikulasikan sebuah tuntutan tertentu. Dalam hal tersebut sosok elit terlihat atas keberadaan tokoh agama dalam setiap organisasi yang berelasi satu sama lain antar organisasi Islam yang dengannya membentuk empty signifier dan menghasilkan beberapa nodal point. Munculnya nodal point didorong pada adanya relasi universalistik yang mengartikulasikan beberapa tuntutan dan permintaan yang tidak terpenuhi.

Berbicara mengenai hegemoni dalam ranah perjuangan berbagai identitas berarti telah melibatkan suatu elemen diskursif tertentu, elemen diskursif menjelaskan berbagai artikulasi dari berbagai elemen organisasi Islam untuk mendefinisikan suatu posisi politik baru. Makna lain dari strategi diskursif adalah partikularistik yang diakomodasi karena diskursus tidak hadir dalam suatu ketunggalan elemen. Ia hadir sebagai wujud diskursif tertentu yakni sebuah jalinan relasi-relasi antar the other. Diskursus merupakan sesuatu yang hanya muncul melalui hubungan diferensial dengan sesuatu yang lain (Laclau, 2005), dalam konteks populisme adalah relasi-relasi. Dengan demikian suatu praktik perjuangan hegemonik berbicara soal partikularitas dalam wujudnya yang plural distrukturkan dalam suatu diskursus. Oleh karena itu perjuangan hegemonik dalam pluralisme adalah jalinan relasi antara berbagai posisi subjek yang memainkan diskursus tertentu untuk membangun suatu tatanan politik baru didasarkan atas adanya persamaan demands dan interest. Hal tersebut dapat dijelaskan dengan skema dibawah yang menjelaskan bagaimana perjuangan hegemonik dalam bentuknya yang diskursif saling bertemu dan menemukan sebuah persamaan yang dengannya membentuk suatu rantai kesetaraan diluar konteks ekonomi seperti dalam terminologi Marx, namun ia bertemu pada kesamaan tuntutan dan suatu agenda. 


\section{Skema No. 2}

\section{Relasi Diskursif dan Perjuangan Hegemonik}

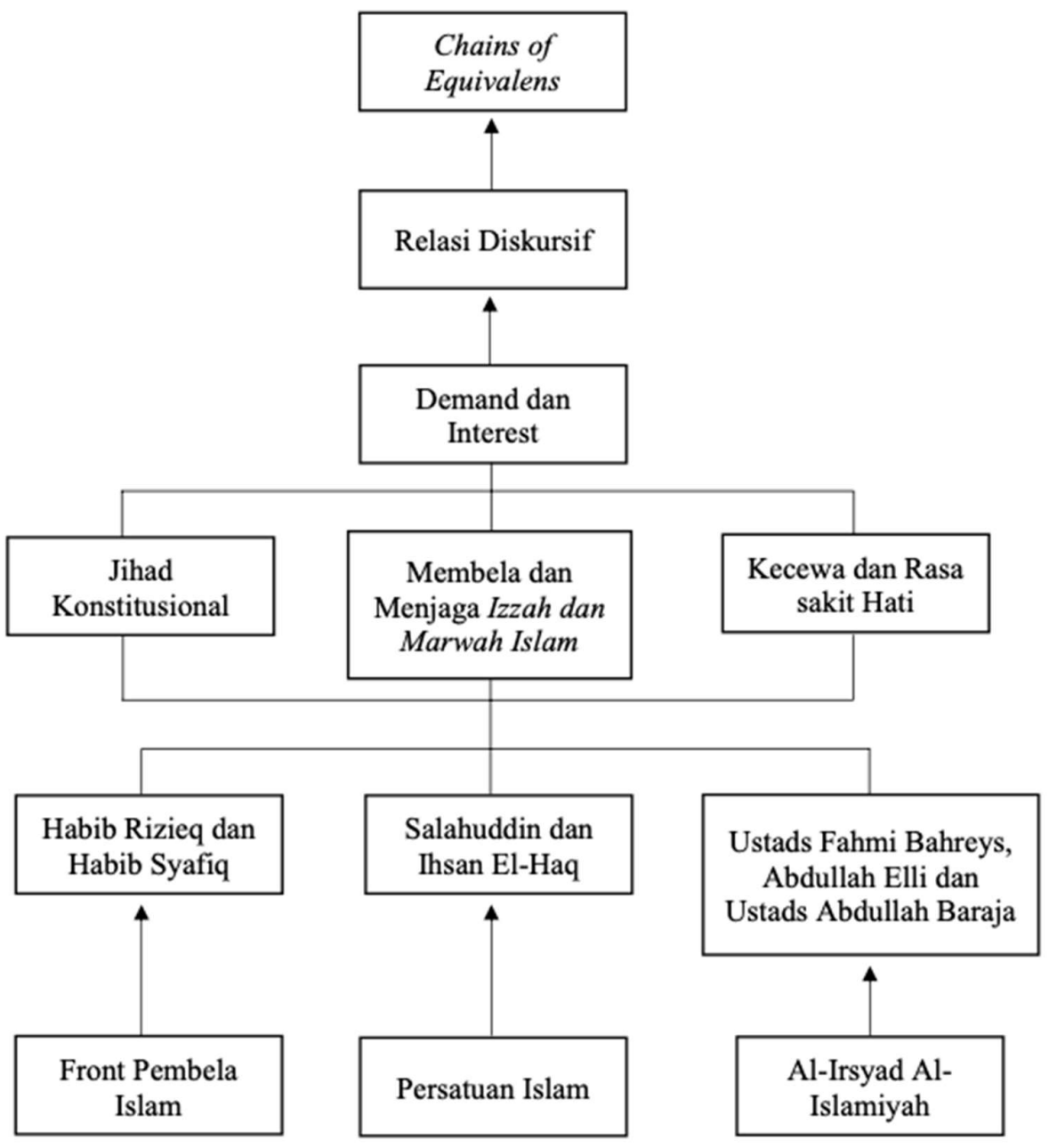

(Hasil Analisa Peneliti, 2021)

Skema diatas menjelaskan bagaimana perjuangan hegemonik dalam bentuknya yang diskursif saling bertemu dan menemukan sebuah persamaan yang dengannya membentuk suatu rantai kesetaraan diluar konteks ekonomi seperti dalam terminologi Marx, namun ia bertemu pada kesamaan tuntutan dan suatu agenda. Relasi diskursif atas elit yang merupakan tokoh agama dalam organisasi Islam membentuk sebuah polarisasi atas adanya elemen universalitas diatas sesuatu yang partikular. Tokoh agama FPI berelasi dengan tokoh agama Persis dan AlIrsyad Al-Islamiyah, yang kesemuanya berdiskursus mengenai tuntutan yang sama. Tokoh agama FPI Habib Rizieq dan Habib Syafiq berbicara mengenai jihad konstitusional dalam gerakan 212, sedangkan Persis, yakni Salahuddin dan Ihsan El-Haq berbicara mengenai keharusan menjaga dan membela izzah dan marwah Islam dan Al-Qur'an, dan Al-Irsyad AlIslamiyah melalui konstruksi Ustadz Fahmi Bahreys, Ustadz Baraja dan Abdullah Elli 
berbicara mengenai rasa sakit hati keharusan untuk mengadili Ahok segera. Melihat hal tersebut relasi diskursif terjalin diketiga elit tokoh agama dari organisasi Islam. Relasi tersebut pada akhirnya terwujud dalam perjuangan hegemonik yang terpolarisasi dalam rantai kesetaaan. Hal ini didasari atas adanya kesamaan tuntutan dan agenda yang pada akhirnya bermuara pada chains of equivalens. Adanya persamaan tuntutan berkonsekuensi pada terbentuknya identitas baru yang melampaui partikularitas antar organisasi terwujud dalam relasi diskursif antar elit antagonis dalam gerakan 212.

Munculnya identitas baru yang didalamnya terbentuk atas relasi diskursif, perjuangan hegemonik dan bermuara pada chains of equivalens kemudian melahirkan suatu penanda kosong atau empty signifier. Suatu penanda menjadi kosong ketika penanda itu berubah dari petanda partikular menjadi simbol rantai petanda-petanda yang equivalen. Empty signifier muncul untuk memainkan fungsi universal karena jalinan relasi diskursif partikularitas diberbagai identitas mengosongkan makna partikularnya dan membentuk penanda umum dalam kaitanya untuk menentang tatanan opresif. Chains of equivalens telah berimplikasi pada empty signifier, dalam konteks gerakan 212. Adanya kesamaan tuntutan dan agenda dalam bentuk demand dan interest menyebabkan diferesnisasi runtuh bersama partikularitasnya dan membentuk suatu persamaan yang bersifat universal yang melahirkan penanda baru dalam wujud identifikasi baru.

Rantai kesetaraan yang terbangun dalam relasi diskursif melalui elit dan tokoh organisasi Islam membentuk sebuah embrio populisme, yang dengannya menjadikan struktur internal populisme terwujud. Keharusan menemukan nodal point dalam konteks gerakan 212 terwujud pada terbentuknya identifikasi baru dalam organisasi Gerakan Nasional Pengawal Fatwa MUI atau GNPF MUI. Transformasi empty signifier atas relasi diskursif dievidenkan atas terbentuknya GNPF MUI merupakan hasil perjuangan hegemonik yang berfungsi untuk menentang tatanan opresif, hal ini membentuk polarisasi diantara tubuh sosial dalam kita vs mereka. Identifikasi musuh bersama dan juga identifikasi mengenai aliansi yang didalamnya memiliki unsur yang universal. Skema di bawah akan menjelaskan bagaimana sebuah struktur internal populisme dapat hadir dan terwujud dengan melewati beberapa mekanisme. 


\section{Skema No. 3}

\section{Struktur Internal dan Embrio Populisme Gerakan 212}

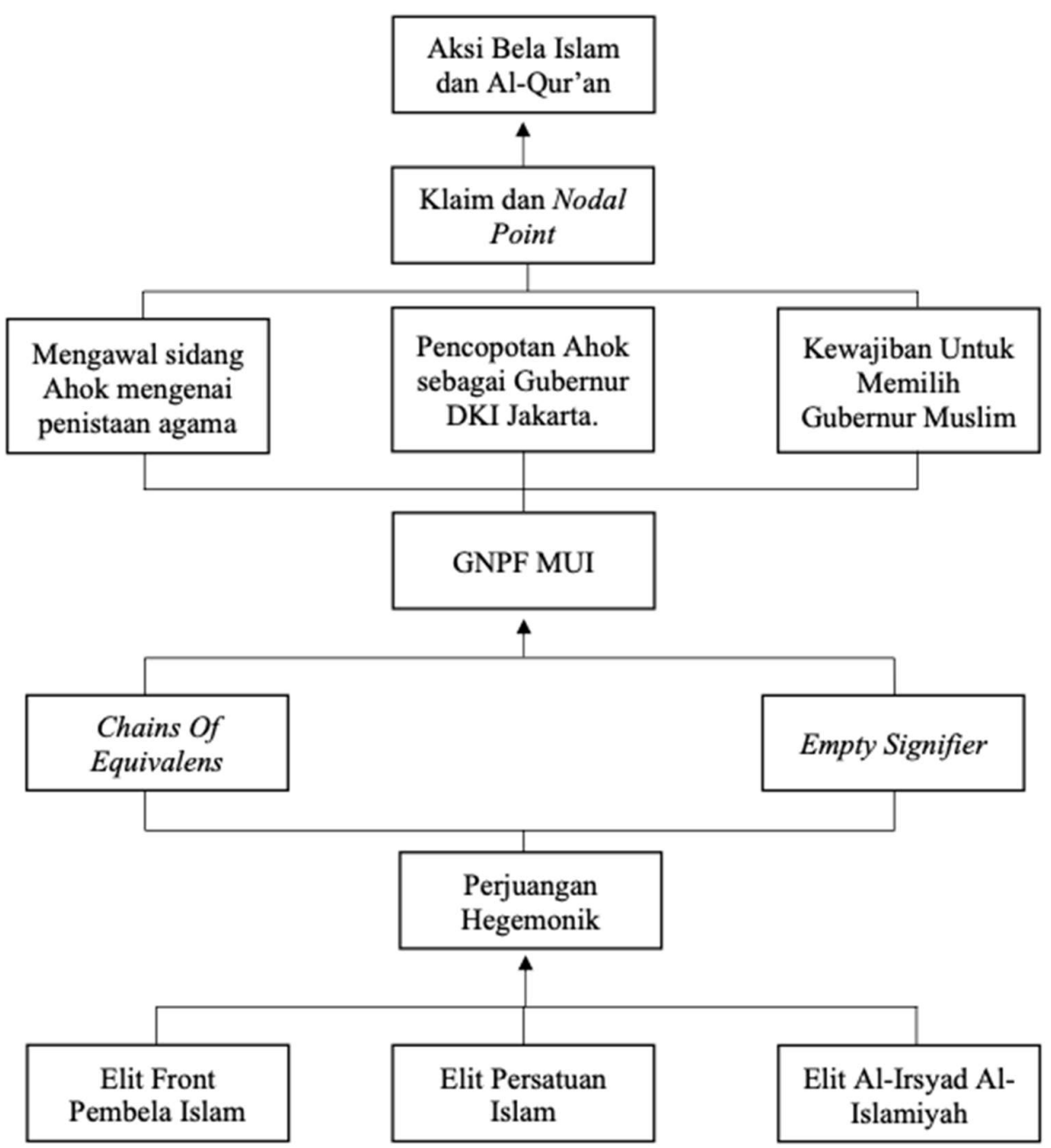

(Hasil Analisa Peneliti, 2021)

Skema No.3, menjelaskan mengenai bagaimana sebuah partikularitas antar organisasi Islam mencapai stabilitasnya dalam struktur internal populismenya, hal ini perlu dilakukan karena munculnya struktur internal populisme merupakan sebuah konstruksi dan perjuangan yang didasarkan pada perluasan logika ekuivalen dengan mengorbankan logika diferensial. Maka dari itu, beberapa hal yang spesifik dan komprehensif merupakan suatu hal yang harus dijelaskan. Diawali dari adanya partikularitas antar organisasi Islam yang merupakan fondasi awal struktur internal populisme. Islam menjadi khazanah dan stock of knowledge pada tataran struktur intersubjektif manusia. Maka, Islam dalam gerakan 212 menjadi sebuah elemen yang mengandung dua unsur sekaligus yakni, sebagai partikularitas sekaligus universalitas, yang akhirnya Islam dapat dijadikan konstruksi pembentukan chains of equivalens dalam organisasi 
populis dan dapat menjadi embrio populisme yang melampaui logika struktur kelas dan basis kelas dalam gerakan 212. Diketahui, struktur internal populisme hanya dapat dibentuk melalui partikularitas dan perbedaan yang terdiferensiasi, sekaligus didalamnya memiliki unsur persamaan yang harus diperjuangkan, karena kesetaraan tidak dapat tercipta dengan sendirinya. Maka, ia harus didorong melalui berbagai relasi diskursif dan artikulasi hegemonik. Hal ini berimplikasi pada keharusan terdapat elit antagonis dalam struktur populisme. Elit antagonis yang merupakan subjek politik dalam embrio populisme, yang dengannya membentuk rangkaian chains equivalens hingga terbentuknya empty signifier yang didasarkan atas konstruksi tuntutan dan agenda, demands dan interest. Jika hal tersebut sudah terwujud maka, dibutuhkan sesuatu yang lebih kosong untuk melampaui partikularitasnya masing-masing. Dalam gerakan 212, kekosongan terwujud dalam transformasi empty signifier dan chains equivalens yang membentuk identifikasi baru yakni GNPF MUI yang merupakan organisasi yang sudah setara antar beragam tuntutan.

GNPF MUI merupakan titik krusial yang harus merumuskan suatu klaim dan nodal point, karena hal itu merupakan stabilitas dari universalitas yang merupakan upaya pengorbanan partikular diantara organisasi Islam. Maka, GNPF MUI yang merupakan transformasi chains equivalens dan empty signifier merumuskan sebuah nodal point yang didasari atas partikularnya tuntutan. GNPF MUI diketahui memiliki agenda berupa mengawal sidang Ahok sebagai penista agma, pencopotan Ahok sebagai Gubernur DKI Jakarta dan kewajiban untuk memilih pemimpin muslim. Kesemuanya merupakan sebuah usaha partikularistik dan hasil rantai kesetaraan antar partikularitas, dengan deklarasi tersebut maka GNPF MUI merupakan identifikasi kosong yang mampu menyerap berbagai partikularitas antar organisasi Islam yang tidak lepas dari perjuangan hegemonik dikalangan elit melalui relasi diskursif yang diketahui dilakukan melalui musyawarah bersama antar organisasi Islam yakni FPI, Al-Irsyad Al-Islamiyah dan Persis dibawah bendera GNPF MUI untuk menentukan agenda tertentu yang dapat melampaui diferensiasi partikular tersebut. Nodal point tersebut pada akhirnya bermuara pada klaim bahwa gerakan 212 merupakan aksi bela Islam dan AlQu'an. GNPF MUI sebagai wujud ketertiban partikularitas dan sebagai penentu stabilitas yang akan memenuhi segala tuntutan yang dihasilkan dari chains of ekuivalens.

\section{Gerakan Populisme 212 Sebagai Gerakan Politik}

Jika pada bagian sebelumnya telah dijelaskan mengenai embrio populisme yang dibentuk oleh berbagai relasi-relasi diskursif yang membentuk rantai kesetaraan antar organisasi Islam yakni FPI, Persis dan Al-Irsyad Al-Islamiyah, maka dalam subab ini akan dijelaskan lahirnya populisme Islam dalam wujud gerakan 212. Populisme berangkat dari 
adanya sebuah momentum yang didasari oleh demands dan interest berupa tuntutan sosial. Tuntutan tersebut kemudian terakumulasi dengan tuntutan-tuntutan dalam chain of equivalence yakni situasi yang setara dalam kadar pemaknaan tuntutan. Relasi diskursif dalam perjuangan hegemonik juga terwujud dari keberadaan elit dari ketiga organisasi tersebut. Perjuangan hegemonik antar organisasi Islam telah melahirkan elemen populisme yang berupa, relasi diskursif, chains of equivalens, empty signifier dan nodal point. Ketiga elemen tersebut kemudian menyatu dan membentuk suatu polarisasi yang terwujud pada GNPF MUI.

Polarisasi tersebut membuktikan bahwa terdapat perbatasan politik atau political frontier dalam tubuh sosial. Jadi, adanya hal tersebut maka lahir sebuah formasi perbatasan internal, dikotomisasi spektrum politik lokal melalui munculnya rantai ekuivalen. Populisme adalah pembentukan perbatasan antagonis internal yang memisahkan struktur antagonis dan struktur protagonis. Struktur antagonis merupakan struktur yang melawan sedangkan struktur protagonis merupakan struktur yang dilawan, hal ini merupakan dikotomisasi yang lahir atas embrio yang sudah dijelaskan dalam subab sebelumnya. Ketika ekuivalensi terbentuk, dan beroposisi dengan penguasa, maka terjadilah sebuah momentum antagonisme atau pertentangan, pertentangan inilah yang disebut political frontier dalam kerangka populisme (Laclau, 2005). Populisme sangat bergantung pada kehadiran perbatasan dikotomis, tanpa perbatasan tersebut, chains of equivalens akan runtuh dan nodal point akan lenyap dalam kekhususan diferensialnya kembali.

Terbentuknya polarisasi dalam gerakan populisme didasari oleh relasi equivalensi yang berarti menciptakan dan mendefinsikan siapa yang menjadi lawan atau adversary. Seperti yang diungkapkan Laclau bahwa, “jika seseorang ingin membangun rantai kesetaraan di antara perjuangan demokratis, seseorang perlu membangun perbatasan dan menentukan musuh, tetapi ini tidak cukup. Seseorang juga perlu tahu untuk apa dia berjuang, masyarakat seperti apa yang dia ingin bangun (Laclau and Mouffe, 2001).” Dari adanya hal itu, maka populisme dapat memanifestasikan tidak hanya gerakan sosial tapi juga gerakan politik. Hal tersebut didasari atas terciptanya suatu momentum antagonisme dan memungkinkan terjadinya gerakan sosial politik. Dalam bagian ini gerakan populisme 212 yang menghadirkan GNPF MUI sebagai struktur organisasi populis menciptakan political frontier terhadap relasi operesif, yakni relasi subordinasi yang melahirkan antagonisme. Relasi operesif dalam gerakan 212 adalah Ahok sebagai elit protagonis serta elit pendukungnya berdasarkan organisasi Islam yang saling bertentangan yakni, Jamaah Tabligh dan pengikut pemahaman Salafi. 
Skema No. 4

Gerakan Populisme 212

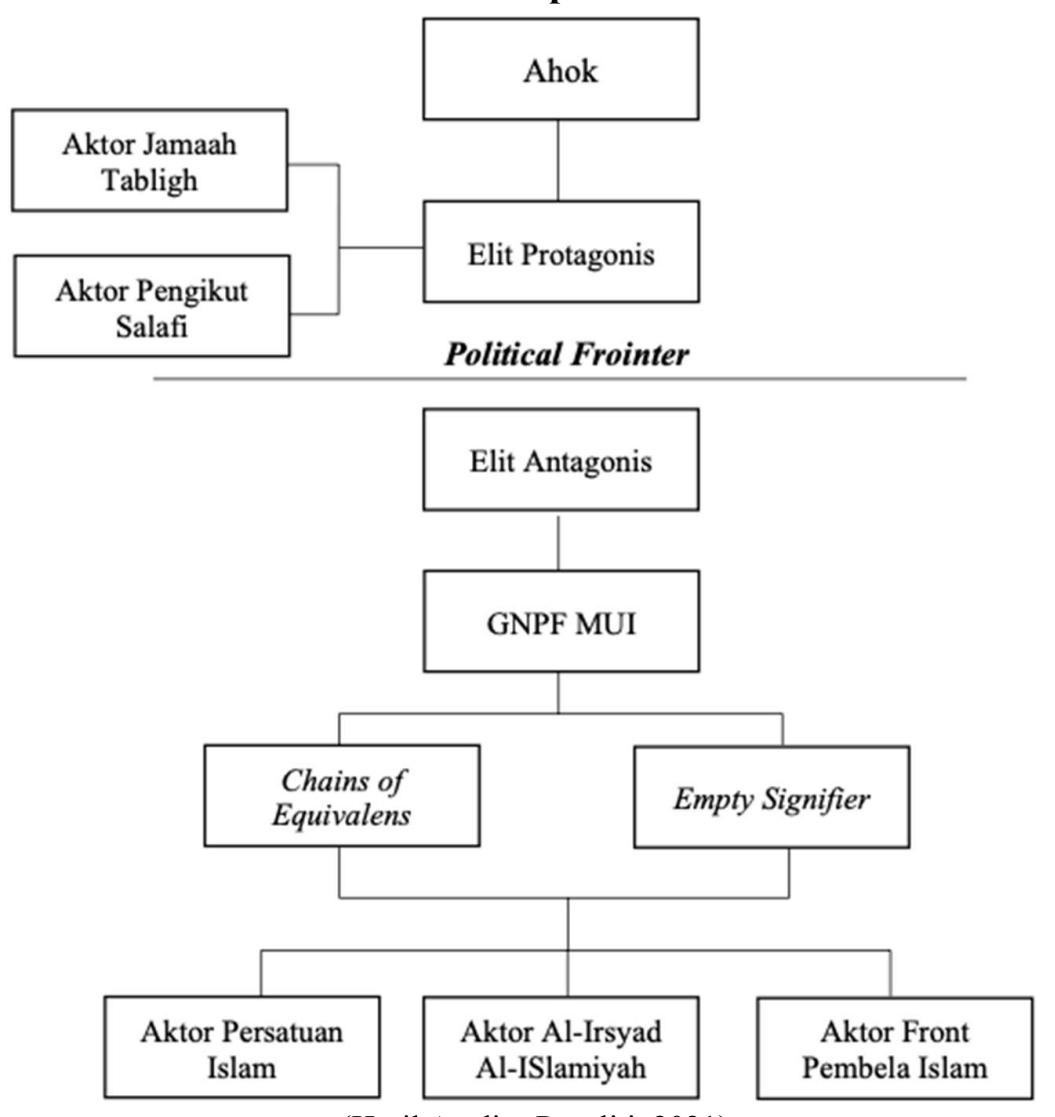

(Hasil Analisa Peneliti, 2021)

Dalam skema diatas dapat dijelaskan mengenai terjadinya gerakan populisme 212, yang menghadirkan sebuah antagonisme dalam tubuh sosial. Antagonisme tersebut muncul didasarkan oleh adanya relasi operatif, yang berbicara mengenai relasi subordinasi yang melahirkan antagonisme. Munculnya antagonisme ini tidak hanya ada karena praktik represif dalam relasi kekuasaan namun juga dikondisikan oleh eksterior diskursif yang berperan untuk menggugah kesadaran akan posisi diopresi (Juru, 2010:203). Jadi, munculnya pertentangan adalah hasil sebuah relasi yang dikonstruksi sedemikian rupa yang akhirnya memunculkan kesadaran reflektif terhadap situasi sedang diopresi. Dalam gerakan 212, perkataan Ahok mengenai Al-Maidah 51, yang merupakan sebuah serangan terhadap struktur obyektif berimplikasi pada munculnya kesadaran reflektif untuk menuntut dan lahirnya sebuah agenda dan tuntutan agar Ahok segera diadili. Antagonisme yang muncul dalam gerakan 212 juga berimplikasi pada terciptanya sebuah tapal batas politik atau political frontier. Hal tersebut telah mengkonstruksi sebuah adversary yakni, proses mendefinisikan siapa lawan. Seperti data yang sudah diperoleh maka, gerakan populisme 212 terwujud dari adanya penyetaraan identifikasi hingga pembentukan identifikasi baru melalui beberapa tahapan yang 
mengecualikan perbedaan dalam tiap-tiap partikularitas organisasi Islam. Munculnya chains of equivalens dan empty signifier menciptakan sebuah klaim dalam nodal point tertentu yang menghasilkan beberapa agenda dan juga tuntutan. Elit antagonis yang menjalin relasi diskursif satu sama lain hingga membentuk identifikasi GNPF MUI menjadi titik lahirnya populisme Islam.

Menyatunya berbagai organisasi Islam dalam GNPF MUI merupakan sebuah usaha untuk melampaui perbedaan yang sudah dikonstruksi sebelumnya hingga munculnya identifikasi baru penentang elit, penciptaan oposisi dalam tubuh sosial. Hal ini merupakan sebuah momen-momen yang akhirnya menciptakan sebuah momentum besar gerakan populisme dengan logic dan implikasi politik. Hal ini bisa dibuktikan pada tataran implikasi dan dampak dari munculnya gerakan populisme 212. Kemudian, pada tataran elit protagonis, yakni Ahok yang memanifestasikan kemunculan relasi operesif dalam tubuh sosial tidak berdiri sendiri, namun terdapat beberapa organisasi Islam yang mendukung kemapanan terhadap elt protagonis tersebut dan dalam gerakan 212 diposisikan sebagai elit pendukung protagonis dan kemapanan. Hal tersebut sesuai dengan tidak tercapainya perjuangan hegemonik terhadap keseluruhan organisasi Islam yang berimplikasi pada masih terdapat beberapa organisasi Islam yang menolak dan tidak setara terhadap gerakan 212. Jamaah tabligh dan Salafi menjadi dua organisasi yang memposisikan pada disposisinya terhadap elit protagonis.

Political frontier dalam gerakan populisme 212 menunjukkan adanya antagonisme yang dikonstruksi oleh berbagai elit dalam tubuh sosial, diantaranya Jamaah Tabligh terdapat Ustadz Ican atau biasa disapa Gus Ican dan di Salafi sendiri terdapat Ustadz Novtriadi, kedua elit tersebut saling menginternalisasi sebuah pertentangan melalui adanya prinsip, ideologi dan kegiatan organisasi yang menilai bahwa tidak ikut dalam gerakan 212 dan menghimbau pada para jamaah dan anggotanya untuk tidak hadir dalam gerakan 212. Jamaah Tabligh dan Salafi memposisikan diri pada supporting terhadap elit protagonis dan kemapanan, tetapi keduanya tidak lepas dari belenggu antagonisme gerakan 212 dalam tubuh sosial. Populisme didasari oleh terbentuknya chains of equivalens yang memiliki artian sebuah cara politik untuk memobilisasi massa dan menyatukan berbagai elemen manusia dari beragam partikularitasnya. Ia tercampur dan bertumpuk dalam satu agenda politik. Maka dari itu, terdapat beberapa elemen lain di luar organisasi Islam ikut terlibat dalam gerakan populisme 212 ini menandakan terbentuknya sebuah rantai kesetaraan diantara berbagai elemen pada tubuh sosial masyarakat. Hal tersebut dibuktikan oleh ikut sertanya basis lain diluar basis Islam yakni yang dikatakan sebagai kelas menengah perkotaan. Merujuk pada tulisan Vedi Hadiz bahwa, Islam bukan 
sebagai satu-satunya rantai kesetaraan dalam populisme Islam, namun basis kelas dan aliansi lintas kelas yang tergabung dalam populisme Islam juga ikut mempengaruhi atas terbentuknya rantai kesetaraan dan empty signifier dalam populisme Islam (Hadiz, 2016:34).

Kelas menengah baru dan terpelajar yang kondisi material kehidupannya bisa sangat berbahaya, telah muncul dari proses modernisasi ekonomi yang telah terjadi di banyak bagian dunia Muslim. Untuk individu kelas menengah seperti itu, beberapa interpretasi Islam dapat memberikan lensa yang berguna untuk memahami dunia sosial yang mereka temui dan tempat mereka di dalamnya (Hadiz, 2016:36). Dari penjelasan tersebut dapat ditarik pemahaman bahwa kelas bawah perkotaan dan pinggiran kota merupakan beberapa elemen yang memungkintkannya untuk tergabung dalam chains of equivalens dalam populisme Islam. Hal ini dibuktikan yakni peserta dalam gerakan 212 tidak hanya kelompok Islam tetapi masyarakat miskin perkotaan korban penggusuran. Mereka adalah masyarakat Kampung Akuarium, Penjaringan, Jakarta Utara yang pernah digusur kampungnya oleh Ahok (Kusumo, 2019:104). Dari adanya hal tersebut maka, mereka mungkin membayangkan sebuah alternatif yang bisa dipalsukan dan yang lebih akomodatif dengan kepentingan dan aspirasi mereka, dalam konteks ini adalah populisme Islam. Sebuah argumentasi dimana bagian-bagian kelas menengah perkotaan dan borjuasi yang terpinggirkan telah berhasil bergabung dengan sebagian besar dari kaum miskin kota yang tidak terorganisir, hasilnya dapat berupa semacam populisme yang secara kuat memanfaatkan kecemasan dan frustrasi lintas kelas ke dalam politik identitas Islam (Hadiz, 2016).

Munculnya populisme Islam juga dimungkinkan oleh adanya transformasi sosial yang terkait dengan kemajuan ekonomi pasar dan tekanan globalisasi yang dialami di sebagian besar dunia Muslim dalam beberapa dekade terakhir, tetapi juga hasil sebelumnya dari Perang Dingin (Hadiz, 2016). Kedua hal tersebut menandai adanya era kapitalisme kontemporer dan kekosongan subjek atas hasil perang dingin. Diketahui parang dingin menghasilkan kekalahan subjek kiri dalam hal ini komunisme didalam arena perang dingin yang berimplikasi pada kekosongan subjek. Kekosongan ini yang merupakan hasil munculnya beragam bentuk populisme horizontal atau sayap kanan yang muncul di abad ke-21. Kemajuan kapitalisme juga ditandai oleh krisis gerakan buruh dan tidak memadainya subjek buruh sebagai subjek atau agen sosial populisme. Kapitalisme kontemporer telah berkembang disegala aspek, membentuk sebuah sekat diantara buruh itu sendiri. Hal inilah yang mendorong kemunculan populisme Islam sebagai pengisi atas kekosongan subjek populis. Jadi, tidak hanya buruh yang dapat membentuk chains equivalens, melainkan subjek dapat dihasilkan dari berbagai relasi diskursif dan perjuangan hegemonik dalam usaha membentuk chains of equivalens dan empty 
signifier. Sebuah subjek baru yang memungkinkan praktik hegemonik demi kemunculan chains of equivalens dan empty signifier dalam kaitannya pada munculnya political frontier.

Populisme adalah sebuah momen dan muncul sebagai sebuah momentum, maka populisme merupakan gerakan yang memiliki damage yang besar, populisme tidak konstan tetapi sekali itu terjadi maka, implikasi dan dampak yang muncul tidak hanya berbicara pada tataran yang bersifat horizontal atau kultural, tapi juga pada tataran vertikal atau politis, dan itu terjadi secara langsung dan dapat kita rasakan pada tubuh sosial sebagai masyarakat. Implikasi yang dapat dirasakan dan terlihat secara langsung adalah terbentuknya polarisasi dalam tubuh sosial masyarakat. Polarisasi inilah yang memberikan implikasi pada tubuh sosial, ekonomi dan juga politik. Seperti data yang menjadi eviden yang telah diperoleh, polarisasi dalam tubuh sosial yang terjadi pada munculnya gerakan populisme 212 meliputi menguatnya persatuan antar organisasi Islam pasca terjadinya gerakan 212. Hal itu meliputi relasi saling membangun dan mendukung antar organisasi Islam ketika salah satu organisasi memiliki isu tertentu.

\section{Skema No. 5}

\section{Partikularitas Organisasi Dalam Gerakan 212}

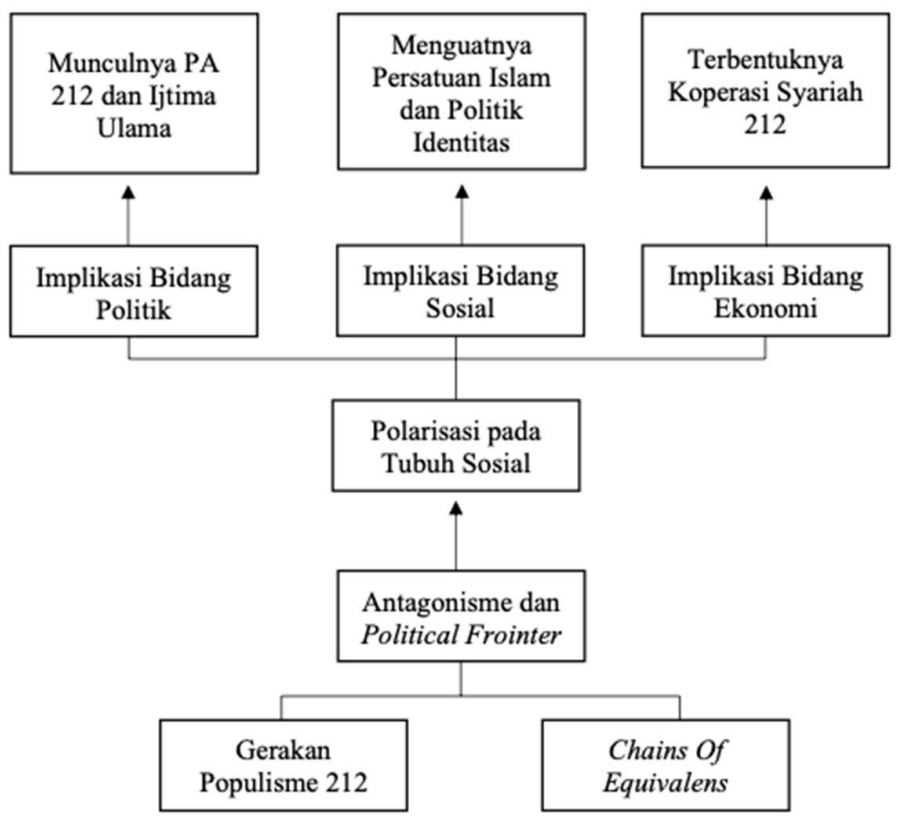

(Hasil Analisa Peneliti, 2021)

Polarisasi pada tubuh ekonomi meliputi bangkitnya ekonomi umat melalui terbentuknya Koperasi Syariah 212 yang didirikan oleh tokoh-tokoh umat Islam sebagai implementasi semangat Aksi 212 yang penuh persaudaraan dan kebersamaan. Semangat ini kemudian diwujudkan pada upaya menjadikan Koperasi Syariah 212 sebagai wadah 
perjuangan ekonomi untuk mencapai kemandirian ekonomi umat Islam. Bahkan, Koperasi Syariah 212 sendiri telah memperoleh legitimasi secara legal hukum dari pemerintah melalui diterbitkannya Surat Keputusan Menteri Koperasi dan usaha Kecil Menengah No. 003136/BH/M.UMKM.2/I/2017 yang dikeluarkan oleh Kementerian Koperasi dan UKM pada tanggal 19 Januari 2017 (http://koperasisyariah212.co.id/wakaf-pengembangan-ekonomiumat/). Dalam koperasi 212 tersebut terdapat beberapa produk komoditas ekonomi yang didistribusikan seperti munculnya 212 mart sebagai representasi ekonomi umat Islam. 212 mart, air mineral 212, koperasi syariah 212 mobile dan wakaf pengembangan ekonomi umat merupakan manifestasi ekonomi dari gerakan populisme 212 yang telah sukses dan berhasil memunculkan chains of equivalens sebagai prasyarat utama populisme.

Polarisasi pada tubuh politik meliputi munculnya Presidium Alumni 212 yang merupakan organisasi yang terlembagakan pasca 212. Presidium Alumni memiliki beberapa manifestasi seperti Ijtima Ulama yang merupakan sebuah wadah politik untuk merekomendasikan suatu pemimpin yang sesuai dengan konstruksi para tokoh agama dan ulama melalui bebrapa musyawarah dan putusan dari beberapa ulama dan tokoh agama lintas ormas yang tergabung dalam PA 212. Ijtima Ulama berperan terkait rencana langkah politik ke depan bagi para ulama, aktivis dan tokoh mengambil oposisi bersama partai kelompok lainnya. Termasuk pernah ikut serta dalam membahas mengenai langkah politik lanjutan setelah Pilpres 2019. Isu mengenai rasial dan agama digunakan oleh para calon penguasa dan menjadi instrumen untuk mendapatkan kekuasaan dalam ranah elektoral, terlepas dari Pilgub dan menyebar hingga Pilkada di berbagai daerah.

Berdasarkan analisis diatas maka, gerakan populisme 212 yang sukses sebagai momentum terciptanya relasi chains of ekuivalens dan empty signifier diantara organisasi Islam serta munculnya political frontier telah memberikan dampak dan implikasi yang mendorong suatu perubahan dalam ranah ekonomi, politik dan sosial. Bukti tersebut telah menguatkan mengenai implikasi pada polarisasi dalam tubuh sosial yang merupakan sebuah perjuangan untuk mencapai pengakuan atau legitimasi dan terbukanya akses-akses terhadap sumber daya dan redistribusi (Mouffe, 2000:130), bagi umat Islam yang memastikan telah berjalannya logika politik dalam gerakan populisme 212. Maka, terjadinya gerakan politik populisme 212 tidak hanya berdampak pada kontestasi Pilgub DKI Jakarta namun, terpolarisasi sampai ke ranah yang paling umum dan mendasar yang berupa implikasi pada aspek penting dan general seperti aspek sosial, ekonomi dan politik dalam konteks masyarakat pada tubuh sosial. 


\section{Gerakan Populisme 212 Sebagai Proyek Emansipasi Dalam Demokrasi ?}

Gerakan populisme Islam 212 yang menghasilkan political frontier telah memunculkan suatu arena baru dalam tubuh sosial yang memiliki konsekuensi dan implikasi terhadap demokrasi Indonesia. Berbagai implikasi dan dampak dari gerakan populisme 212 dapat ditelusuri dengan menarik pemahaman tubuh sosial dan masyarakat. Diketahui dampak dan implikasi gerakan populisme 212 adalah munculnya polarisasi pada tubuh sosial masyarakat akibat konsekuensi tidak berjalannya relasi diskursif, serta perjuangan hegemonik oleh Elit untuk membangun kekuatan secara menyeluruh khususnya dikalangan organisasi Islam. Tidak berjalannya relasi diskursif serta perjuangan hegemonik dalam membangun basis sosial populisme didasari oleh tidak terbangunnya chains equivalens yang lebih merata dalam tubuh sosial, dibuktikan terdapat organisasi Islam yang tidak berelasi secara diskursif melalui GNPF MUI dan tidak terjalinnya chains of equivalens dalam memunculkan political frontier. Maka dapat ditarik pemahaman bahwa di gerakan populisme Islam 212 tidak mampu menjangkau membentuk chains of equivalens yang lebih luas, maka Islam tidak efisien dan kurang relevan sebagai dasar pembentukan basis sosial populisme sehingga ia menciptakan fragmentasinya sendiri dalam organisasi Islam serta menyebar hingga dalam tubuh sosial masyarakat.

Bentuk polarisasi dan fragmentasi gerakan populisme Islam 212 kemudian memberikan dampak serta implikasi pada antagonisme horizontal yakni bangkitnya politik identitas, politik rasialis yang hanya mengarah pada populisme elektoral, hal ini diketahui sebagai wujud tantangan terhadap demokrasi ditengah masyarakat yang plural. Tekanan politik rasialis dan identitas serta bangkitnya isu rasial dibuktikan dari praktik polarisasi dalam tubuh sosial. Sentimen keagamaan dan sentimen rasial dalam tubuh sosial menjadi wajah dan wujud baru demokrasi yang terjadi pada konteks implikasi munculnya gerakan populisme gerakan 212 . Bahkan hal tersebut menjadi sebuah potensi bagi model kepemimpinan yang populis, yang menggunakan jargon, visi-misi dan terma-terma populisme, yang merupakan konsekuensi menguatnya populisme Islam. Janji-janji serta terma digunakan oleh para calon pemimpin guna mendapatkan kekuasaan dan hal ini mengarahkan gerakan populisme 212 hanya mengarah pada populisme elektoral. Kekuatan massa yang besar dan strategis serta mobilisasi yang luas digunakan sebagai gaya dan strategi politik serta sebagai sarana membangun dan memelihara kekuatan politik berdasarkan mobilisasi massa pendukung.

Para pemimpin dan calon pemimpin menggunakan kekuatan ini untuk mempengaruhi logika publik melalui menguatnya populisme Islam untuk mendapatkan dan mempertahankan kendali negara (Barr, 2019:53). Politisasi sentimen- sentimen keagamaan dan kedaerahan yang sempit menjelaskan bagaimana politisasi identitas yang eksklusioner menjadi implikasi dari 
gerakan populisme 212. Orang bahkan bisa menoleransi kemiskinan dan korupsi yang merupakan hal yang harusnya menjadi disensus publik dalam demokrasi, tetapi ngotot terhadap isu politik berbasis identitas. Maka pertarungan politik yang terjadi dalam konteks gerakan populisme 212 lebih banyak diwarnai isu-isu sektarian dan identitas tertentu daripada upaya membangun tatanan demokrasi dan kesejahteraan bersama. Implikasinya, perebutan kekuasaan dan sumber daya dibangun melalui politisasi moral komunitarian sempit seperti munculnya bahasa "kafir", "non- pribumi", dan sejenisnya, ketimbang ditujukan untuk membangun kebaikan bersama melalui mekanisme politik demokrasi (Mudhoffir, 2020:132). Fragmentasi populisme Islam dan reaksi yang berkembang pada antagonisme horizontal merupakan respons yang kontraproduktif bagi demokrasi itu sendiri. Secara performatif, artikulasi dan retorika populisme Islam sangat eksklusionaris. Dengan kata lain, Islam yang diartikulasikan dan menjadi embrio struktur internal populisme itu lebih memiliki efek memecah daripada menyatukan elemen-elemen politik melalui isu keadilan dan kesejahteraan bersama. Dalam kasus Pilgub Jakarta 2017 menciptakan kontestasi wacana mengenai Islam dan membentuk blok dikotomi politik anti- Ahok dan pro-Ahok dalam politik elektoral, mereka sama-sama menggunakan Islam sebagai penanda politik (Mudhoffir, 2020:135).

Namun, jika gerakan populisme berbasis Islam dalam gerakan 212 ditelisik melalui pemahaman demokrasi radikal, maka populisme Islam gerakan 212 dapat menjadi peluang bagi munculnya subjek politik baru dalam mengisi kekosongan subjek. Demokrasi radikal melihat ketidakmampuan demokrasi modern untuk menentukan subjek politik karena demokrasi modern melihat bahwa semua manusia itu bebas dan sederajat, dan meyakini bahwa tidak mungkin menemukan prinsip yang lebih radikal untuk mengorganisir masyarakat jika masyarakat dilihat secara individual dalam terminologi hak-hak yang menghasilkan belenggu dalam masyarakat, karena ia mengabaikan relasi dan bentuk pluralisme dalam tubuh sosial (Mouffe, 1992:2). Demokrasi radikal melihat ketidakmungkinan realisasi akhir dari demokrasi modern. Ini menegaskan bahwa ketegangan yang tak dapat dipecahkan dengan menggunakan prinsip-prinsip kesetaraan dan kebebasan sebagai akhir dan juga sebagai syarat utama, karena hal ini akan mengakibatkan penghapusan politik dan negasi demokrasi (Mouffe, 1992:6). Perangkat yang diperlukan agar masyarakat demokratis berfungsi adalah seperangkat lembaga dan praktik yang merupakan kerangka kerja konsensus di mana pluralisme bisa ada. Dengan cara sedemikian rupa komunitas politik demokratis modern harus dipahami, sebagai permukaan prasasti diskursif, bukan rujukan empiris dan akhir dari perjuangan. Hanya dalam kerangka seperti itu konstruksi pemaknaan dan tafsir terhadap realitas akan selalu yang saling bersaing tentang prinsip-prinsip persamaan dan kebebasan. 
Pengalaman demokrasi radikal dan plural hanya dapat berdiri dari pengakuan akan keanekaragaman logika sosial dan perlunya artikulasi dan perjuangan mereka. Akan tetapi artikulasi dan perjuangan tersebut harus selalu diciptakan kembali dan dinegosiasikan ulang dan tidak ada harapan untuk mewujudkan rekonsiliasi akhir. Inilah mengapa demokrasi radikal juga berarti kemustahilan radikal dari demokrasi yang tercapai sepenuhnya (Mouffe, 1992:10). Populisme menjadi salah satu wujud demokrasi radikal, karena ia selalu menitikberatkan pada suatu relasi diskursif dalam perbedaan dan partikularistik, hingga ia membentuk suatu chains of equivalens yang bersifat sementara dan terus membentuk disensus dalam demokrasi. Dengan itu populisme menjadi sebuah kekuatan politik, yang dapat menyasar agenda dan tuntutan ke dalam wacana yang lebih luas, dan membantu membangun bentuk organisasi dan tingkat akuntabilitas, serta memastikan bahwa kepentingannya terwakili dan dikejar dalam ideologi politik dan kebijakan publik (Panizza, 2005:202).

Dari pemaparan diatas maka dapat ditarik pemahaman antara populisme gerakan 212 dan relevansinya terhadap demokrasi radikal. Populisme yang mnghadirkan suatu antagonisme melalui terciptanya political frontier, yang mana antagonisme tersebut dalam demokrasi radikal menjadi sesuatu yang harus diperjuangkan. Melihat meluasnya pluralisme identitas yang juga relevan dengan fenomena gerakan populisme Islam 212 maka antagonisme atas dasar identitas menjadi sesuatu yang memungkinkan bagi terbentuknya populisme yang akan menjadi struktur antagonisme dalam political frontier. Bertransformasinya relasi antagonistik ke arah agonistik merupakan penentu bagi perjuangan demokrasi radikal. Relasi agonistik yang merupakan transformasi dari pertentangan antagonisme harus diperjuangkan dan diwujudkan dalam emansipasi politik bagi pemenuhan demokrasi.

Disini peneliti menggunakan konsep populisme Laclau secara terbatas seperti halnya Vedi Hadiz yang merupakan rujukan utama dalam penelitian ini menjelaskan gejala populisme Islam. Hal tersebut didasari atas konsep populisme secara umum yang merupakan terminologi yang lentur dan cair sebagai istilah maupun teori. Populisme dapat ditemui pada istilah dan teori seperti ekonomi populis, populisme sayap kanan di Eropa, Amerika Serikat maupun Amerika Latin. Ditelisik dari konteks sejarah dan perkembangannya yang dimulai dari gerakan buruh yang syarat akan bentuk populisme vertikal, maka dalam kemajuan kapitalisme kontemporer, populisme dapat menjadi pemenuhan atas kekosongan subjek terhadap kapitalisme kontemporer.

Maka dari itu, peneliti dalam menjelaskan populisme Islam 212 tetap menggunakan teori Laclau secara terbatas guna memahami populisme sebagai sebuah cara politik untuk memobilisasi massa, menyatukan orang dari berbagai elemen dan partikularnya yang belum 
memiliki bobot nilai. Dalam hal ini, bobot nilai harus dipahami sebagai proyek emansipasi yang didalamnya tidak didasarkan atas dasar positif apapun dan tidak transenden serta perjuangannya dititikberatkan pada kebebasan dan persamaan. Dalam hal ini, demokrasi radikal-plural memerlukan pluralisasi demokrasi dan pemindahan revolusi demokratik ke wilayah sosial. Jadi, dalam fenomena gerakan populisme 212, walaupun gerakan tersebut belum memiliki bobot nilai emansipasi, namun populisme ala Laclau dapat menjelaskan fenomena gerakan 212 secara lebih komprehensif dengan melihat bagaimana mobilisasi massa didasarkan atas chains of equivalens dan empty signifier yang pada akhirnya bermuara pada munculnya political frontier. Gerakan populisme 212 bukanlah gerakan salah satu elemen partikular seperti gerakan Islam radikal, ia merupakan sebuah gerakan populisme yang dapat mengisi kekosongan subjek dalam usaha mewujudkan demokrasi radikal. Peneliti mengakui bahwa terdapat perbedaan sifat dasar dalam menjelaskan populisme Laclau dengan gerakan Islam 212. Perbedaan ini terdapat pada unsur tidak adanya bentuk emansipasi dalam gerakan 212 yang masih didasarkan semata-mata partikular, karena dalam populisme Laclau sendiri, populisme merupakan sebuah rangkaian teori yang secara praktik dapat digunakan sebagai perwujudan subjek politik baru dalam proyek emansipasi.

Melihat hal tersebut, gerakan populisme 212 dapat menjadi suatu peluang potensial dan bagi terciptanya relasi antagonistik, karena terdapat struktur internal populisme yang telah menghadirkan relasi chains of ekuivalens sebagai pembentukan solidaritas masyarakat pluralisme. Gerakan populisme 212 dapat menjadi peluang bagi terwujudnya demokrasi radikal dan politik emansipasi baru dalam kapitalisme kontemporer, jika gerakan populisme dapat bertransformasi dari relasi antagonistik menjadi agonistik dan juga jika gerakan populisme 212 dapat bobot nilai emansipasi didalamnya. Relasi konfliktual tersebut terutama harus didasari oleh etika kepolitikan sehingga konflik memiliki nilai konstruktif bagi perkembangan demokrasi dan kapitalisme kontemporer. Selain itu, semangat egalitarian yang tercermin dalam etika kepolitikan menjadi alasan bagi subjek politik baru untuk menentang keberadaan rezim yang opresif dewasa ini dan gerakan populisme 212 menjadi potensial sekaligus peluang dalam mewujudkan demokrasi radikal, walaupun ia belum sepenuhnya sempurna dan ideal. Maka dapat ditarik pemahaman dalam melihat tantangan sekaligus peluang yang sudah dijelaskan diatas maka, populisme bukanlah bentuk cita-cita demokrasi tertinggi maupun musuhnya, tetapi ia merupakan cerminan dimana demokrasi dapat merenungkan dirinya sendiri dan mencari tahu tentang dan apa yang kurang dan apa yang harus diperjuangkan. 


\section{Penutup}

Penelitian ini dilakukan untuk memahami relasi dari berbagai organisasi keagamaan Islam yang merupakan basis sosial dari munculnya gerakan populisme 212. Fokus penelitian ditekankan pada fenomena relasi diskursif hingga perjuangan hegemonik diantara organisasi Islam hingga membentuk sebuah struktur internal populisme, yang pada akhirnya bermuara pada political frontier dan dikotomi diantara berbagai elit yang mengisi ruang-ruang antagonisme dalam gerakan 212. Lebih daripada itu kontekstual mengenai implikasi dan dampaknya terhadap masyarakat dan demokrasi juga dijelaskan dalam penelitian ini.

Basis sosial dari struktur internal populisme dalam gerakan 212 terdiri dari beragam organisasi Islam yang didalamnya memiliki jurang perbedaan perihal ideologi, prinsip serta aktivitas kegiatan. Basis struktur internal dari populisme 212 tersebut diantaranya FPI, Persis dan Al-Irsyad Al-Islamiyah dan memliki aktor masing-masing dalam mewujudkan struktur internal populisme. Aktor dalam ketiga organisasi tersebut pada akhirnya menjalin aliansi atas relasi diskursif yang pada akhirnya membentuk identifikasi baru yakni GNPF MUI. Maka, GNPF MUI merupakan sebuah identifikasi baru yang menjadi aktor utama dari populisme gerakan 212. GNPF MUI beserta para aktor didalamnya menjadi dasar pembentukan elit antagonis. Melihat populisme merupakan relasi antar aktor maka, elit antogonis harus diletakkan pada dikotominya terhadap elit protagonis. Dalam konteks gerakan 212, elit protagonis meliputi Ahok sebagai elit opresif, Jamaah Tabligh dan Salafi sebagai pendukung elit yang keduanya masuk kedalam spektrum protagonis dalam fenomena gerakan populisme 212.

Dalam fenomena gerakan populime 212, hal itu terjadi atas terbentuknya fondasi awal struktur internal populisme. Islam menjadi khazanah dan stock of knowledge pada tataran struktur intersubjektif manusia. Maka, Islam dalam gerakan 212 menjadi sebuah elemen yang mengandung dua unsur sekaligus yakni, sebagai partikularitas sekaligus universalitas, yang akhirnya Islam dijadikan konstruksi pembentukan chains of equivalens dalam organisasi populis dan embrio populisme karena telah melampaui partikularitas perbedaan antar organisasi Islam dalam gerakan 212. Antagonisme yang merupakan syarat terbentuknya populisme muncul didasarkan oleh adanya relasi operatif oleh Ahok yang dikonstruksi sedemikian rupa oleh para aktor populis yang akhirnya memunculkan kesadaran reflektif terhadap situasi sedang diopresi. Dalam gerakan 212, perkataan Ahok mengenai Al-Maidah 51, yang merupakan sebuah serangan terhadap struktur obyektif berimplikasi pada munculnya kesadaran reflektif untuk menuntut dan lahirnya sebuah agenda dan tuntutan agar Ahok segera diadili. Hal inilah yang melatarbelakangi lahirnya populisme Islam dalam wujud gerakan 212. 
Munculnya chains of equivalens dan empty signifier dalam gerakan populisme 212 menciptakan sebuah klaim dalam nodal point yang menghasilkan beberapa agenda dan juga tuntutan. Hal inilah merupakan sebuah momen-momen yang akhirnya menciptakan sebuah momentum besar gerakan populisme dengan dengan berbagai implikasi dan konsekuensinya terhadap demokrasi.

Populisme Islam gerakan 212 juga merupakan sebuah tantangan sekaligus dapat menjadi sumber daya yang potensial bagi terwujudnya demokrasi radikal. Populisme juga bukanlah bentuk cita-cita demokrasi tertinggi maupun musuhnya, tetapi ia merupakan cerminan dimana demokrasi dapat merenungkan dirinya sendiri dan mencari tahu tentang dan apa yang kurang dan apa yang harus diperjuangkan. Maka dari itu, populisme dapat menjadi sebuah kekuatan besar bagi demokrasi dan masyarakat tergantung pada tuntutan dan agenda yang akan diperjuangkan, karena populisme merupakan sebuah strategi yang dengannya dapat digunakan untuk tujuan dan intensi apapun. Ia dapat membawa kebaikan dan juga dapat menjadi marabahaya bagi kehidupan umat manusia.

\section{Daftar Pustaka}

Abts, Koen, dkk. 2019. Populism in Belgium The Mobilization Of The Body Anti-Politic, New York: Routledge Taylor and Francis Group.

Barr, Robert R. 2019. Populism as a Political Strategy. New York: Routledge Taylor and Francis Group.

Hadiz, Vedi R. 2016. Islamic Populism in Indonesia and the Middle East. United Kingdom: Cambridge University Press.

Hutagalung, Daniel. 2008. Kata Pengantar Hegemoni dan Strategi Sosialis: Postmarxisme dan Gerakan Sosial Baru. Yogyakarta: Resist Book.

Juru, Ignasius Jaques. 2010. Radikalisasi Pluralisme sebagai Usaha Pengarusutamaan Politik Agonistik. JSP. Vol 14, No 2.

Koperasi Syariah 212, 2019, Profil Koperasi Syariah 212, (http://koperasisyariah 212.co.id/wakaf-pengembangan-ekonomi-umat/).

Kusmanto, Thohir Yuli. 2017. Gerakan Sosial Keagamaan pada Komunitas Urban: Studi Gerakan Pengajian Ahad Pagi. Universitas Islam Semarang, Vol 1, No 1.

Kusumo, Rangga. 2019. Populisme Islam di Indonesia: Studi Kasus Aksi Bela Islam oleh GNPF-MUI Tahun 2016-2017. Universitas Indonesia. Vol 4, No 1.

Kutha, Nyoman. 2016. Metodologi Penelitian. Yogyakarta: Pustaka Belajar.

Laclau, Ernesto. 2005. On Populist Reason. New York: Verso. 
Laclau, Ernesto dan Chantal Mouffe. 2001. Hegemony and Socialist Strategy Towards a Radical Democratic Politics, New York: Verso.

Marchart, Oliver. 2018. Thinking Antagonism Political Ontology After Laclau. United Kingdom: Edinburgh University Press Ltd.

Margiansyah, Defbry. 2019. Populisme Di Indonesia Kontemporer: Transformasi Persaingan Populisme Dan Konsekuensinya Dalam Dinamika Kontestasi Politik Menjelang Pemilu 2019. LIPI, Vol 16, No 1.

Mouffe, Chantal. 1992. Dimensions Of Radical Democracy. New York: Verso.

Mouffe, Chantal. 2000. The Democratic Paradox. New York: Verso.

Mudhoffir, Abdil Mughis, dkk. 2017. Populisme dan Tantangan Demokrasi di Indonesia. Depok: Jurnal Prisma.

Mudhoffir, Abdil Mughis. 2020. Islamic Populism and Indonesia's illiberal Democracy. Singapore: ISEAS.

Panizza, Francisco. 2005. Populism and Mirror of Democracy. New York: Verso. 